\title{
Student Response Systems (SRS) and the Performance of First-Generation Students Majoring in Business
}

\author{
Ricardo Cunningham* \\ a University of Dubuque, 2000 University ave. Dubuque, IA 52001. \\ *Corresponding author's email address: rcunning@dbq.edu
}

\section{A R T I C L E I N F O}

Received: 20-06-2016

Accepted: 10-07-2016

Available online: 25-08-2016

Keywords: First-generation students, student response systems, SRS, technological pedagogy

JEL Classification: M00

\section{A B S T R A C T}

Traditionally, first-generation college students (students whose parents didn't attend college) are at a distinct disadvantage in regards to academic performance and outcomes at post-secondary institutions; and according to the literature, the most commonly declared major of first-generation students is business. Student response systems (SRS) are an in-class student polling technology that is designed to create an engaging and inviting learning environment that maximizes active learning. This study seeks to determine if SRS causes a significant improvement in the exam scores for first-generation college students majoring in business exposed to SRS compared to firstgeneration college students majoring in business not exposed to SRS.

This is an open access article under the terms of the Creative Commons Attribution License 4.0, which allows use, distribution and reproduction in any medium, provided the original work is properly cited.

DOI: http://dx.doi.org/10.18533/job.v1i4.45

ISSN: 2380-4041 (Print), 2380-405X (Online)

Biography: Ricardo Cunningham is an associate professor in the School of Business \& Accounting at the University of Dubuque who holds a DBA from Anderson University. Ricardo's research interests include pedagogical technology, use of talent in business organizations and diversity initiatives.

\subsection{Introduction}

Why do some students succeed in college while others do not? Specifically, why are some types of students predictably more likely to graduate college, while others consistently pose retention problems? In particular, first-generation college students pose notable retention concerns. The U.S. government's educational opportunities program defines a first-generation college student as someone with neither parent having completed a four-year college degree in the U.S. by the time that student entered college. First-generation students are less likely to graduate than peers who have at least one parent with a college education (Chen, 2005). According to the National Center for Educational Statistics, first-generation students persistently have lower GPAs (2.5 vs. 2.8) throughout their college career than students whose parents have bachelors' or higher degrees. Also first-generation students are more likely to withdraw or repeat courses they have attempted, with $12 \%$ of first-generation students withdrawing or repeating a course compared to only $7 \%$ for students whose parents have bachelors' or higher degrees (Chen, 2005). Lower exam scores contribute to lower GPAs and to the withdrawing from or repeating of courses that first-generation students have attempted. This outcome of lower exam scores, with its impact on both lower GPA and on the withdrawing from and repeating of courses, contributes to a disproportionately low number of first-generation students graduating from college. According 
to the National Center for Educational Statistics, only 24\% of first-generation students obtained a bachelor's degree or higher, compared with $68 \%$ of students whose parent(s) had a bachelor's or higher degrees (Chen, 2005).

First-generation college students have been the focus of a growing body of research. Generally, this research falls into three main categories (Tetrazzini, Springer, Yaeger, Pascerella, \& Nora, 1996; Pascerella et al., 2004). The first category consists of studies that typically compare first- and second-generation college students in terms of demographic characteristics, secondary school preparation, college choice process, and college expectations (Stage \& Hossler, 1989; Pratt \& Skaggs, 1989; York-Anderson \& Bowman, 1991; Berkner \& Chavez, 1997; Kojaku \& Nunez, 1998; Hossler, Schmidt, \& Vesper, 1999; Horn \& Nunez, 2000; Warburton, Burarin \& Nunez, 2001; Pascerella et al., 2004). The weight of evidence from this research indicates that, compared to second-generation college students, first-generation college students can be at a disadvantage with respect to basic knowledge about post-secondary education (e.g., cost and application process), level of family income and support, educational degree expectations and plans, and academic preparation in high school.

A second general category of research on first-generation college students describes and tries to understand the transition from high school to post-secondary education (Lara, 1992; Terenzini et al., 1996; Rendon, Hope, \& Associates, 1996; Pascerella et al., 2004). As summarized by Tetrazzini et al. (1996) and Pascerella et al. (2004), the evidence is reasonably clear that first-generation students as a group have a more difficult transition from secondary school to college than their peers. Not only do first-generation college students confront all the anxieties, dislocations, and difficulties of any other college student, they also experience substantial cultural as well as social and academic transitions.

The third general category of research on first-generation college students examines their persistence in college, degree attainment, and early career labor market outcomes (Billson \& Terry, 1982; Attinasi, 1989; Richardson \& Skinner, 1992; Horn, 1998; Nunez \& Cuccaro-Alamin, 1998; Choy, 2000; Berkner, Horn, \& Clune, 2000; Warburton et al., 2001; Pascerella et al., 2004). These investigations consistently indicate that compared to second-generation college students, first-generation college students are more likely to leave a four-year institution at the end of the first year. Also, they are less likely to remain enrolled in a four-year institution or be on a persistent track towards a bachelor's degree after three years. Finally, they are less likely to stay enrolled or attain a bachelor's degree within five years. When degree attainment is taken into account, there appears to be little difference between the early career earnings of first-generation college graduates and their peers. However, four to five years after graduation, first-generation college students appear less likely than secondgeneration students to be enrolled in graduate school or a professional degree program.

The focus of the literature in this study will be primarily based on the third general category of literature dealing with post-secondary matriculation and retention. The rationale behind this reasoning is that institutions of higher education have very little direct control over the abilities of first-generation students who matriculate through their doors; therefore the impact must focus on understanding the challenges that first-generation college students face after they have entered post-secondary education. In particular this paper looks at a gap in the literature of first-generations students majoring in business, which according to the research is by far the most popular major and therefore requires attention of researchers.

Student Response Systems (SRS), which have been utilized since the 1960s, are an evolving, in-class-studentpolling technology designed to create an engaging and inviting learning environment that maximizes active learning, especially in large-enrollment lecture classes (Judson \& Sawada, 2002; Ward et al., 2003; Lowery, 2005). SRS helps to off-set the structural constraints of passive learning processes of a traditional lecture environment by allowing students to become active learners which has been found to increase student attendance, comprehension, motivation and overall course satisfaction.

According to the literature business is the most common area of study for first-generation students (Chen, 2005). To help improve the test scores of these students, many institutions have adopted the use of a pedagogical tool called the Student Response System (SRS). The purpose of this study is to determine if SRS would cause a significant improvement in the exam scores for first-generation students majoring in business exposed to SRS compared to first-generation students majoring in business who are not exposed to SRS

The main objective of this study is to determine if student response systems have a statistically significant effect on the improvement of test scores of first-generation college students majoring in business. In order to accomplish the main objective of this study, two specific research objectives will be addressed:

1. Evaluate academic performance of first-generation students majoring in business in classes using SRS (Experimental Group) 
2. Evaluate academic performance of first-generation students majoring in business in classes not using SRS (Control Group)

Based upon the preceding specific objectives, the following research hypothesis has been formulated:

HII: first-generation college students majoring in business will have significantly improved test scores in business classes that use SRS, compared to first-generation college students majoring in business in business who do not use SRS. Through use of independent samples testing, it is hypothesized that the difference between the scores of Test 2 and Test 1 of first-generation students majoring in business in the experimental group will be significantly higher than the difference between Test 2 and Test 1 scores of first-generation students majoring in business in the control group (non-SRS).

The current study was comprised of 164 students over three semesters in principles of marketing courses utilizing a between-group experimental research design. The rational for using this type of design is the use of a field setting in lieu of a laboratory setting for this particular study. The use of field research (actual classes) is appealing for this study because of the resources (money, availability of participants, etc.) that would have been needed for a typical laboratory design. Additionally, the use of a field design reduces the participants' perception, which can lead to bias, that occurs in a laboratory design. Finally, a field design mandated the use of a non-probability judgment sample for this study. Although a probability sample would produce more generalizable results, the lack of resources (ability to pre-select students) makes it impractical.

My findings from this study does show an increase in test scores from students majoring in business who were exposed to SRS compared to students majoring in business who were not exposed to SRS, however the difference was found not to be significant. It is important that first-generation students succeed in college. The baccalaureate degree is an avenue of upward social mobility, representing the single most important rung in the educational attainment ladder in terms of economic benefits (Pascarella, Pierson, Wolniak, \& Tetrazzini, 2004). In addition, as will most likely be the case in the immediate future, the majority of the approximately 10 million jobs that were created between 2000 and today required skills and competencies beyond those acquired in high school (Callan, 2000; Pike \& Kuh, 2005).

In conclusion this article will introduce the challenge of first-generation students in higher education and introduces student response systems and potential outcomes from its usage; finally the methodology, results and conclusion will be presented.

\section{$2.0 \quad$ First-generation students}

First-generation college students have been the focus of a growing body of research due to the challenges that colleges and universities face in the retention of these students. The U.S. government's educational opportunities program defines a first-generation college student as someone with neither parent having completed a four-year college degree in the U.S. by the time that student entered college, and this population makes up an estimated $31 \%$ of U.S. college and university students (Grayson, 1997; Somers, Woodhouse, \& Cofer, 2004; Chen, 2005). However, findings from a 2005 National Center for Educational Statistics report indicate that only $24 \%$ of firstgeneration students obtain a college degree, compared with $68 \%$ of second generation students (Chen, 2005). With this staggering a difference between the graduation rates of first-generation students and their secondgeneration peers, what could be some of the probable causes of this dilemma?

According to the 2005 National Center for Educational Statistics report, first-generation students exhibit the following problems in academia.

- Remedial course taking - the majority of first-generation students (55\%) took some remedial courses during their college years, as compared to $27 \%$ of second-generation students. (Chen, 2005).

- Credits earned-after their first year of college, first-generation students earned an average of 18 credits, compared to 25 credits earned by second-generation students; earning fewer credits in the first year was strongly associated with leaving postsecondary education without earning a degree (Chen, 2005).

- Postsecondary performance-as early as the first year of college, first-generation students did not perform as well as their second-generation peers. First-generation students had lower first-year undergraduate GPAs (2.5 vs. 2.8), and this performance persisted throughout their entire undergraduate career. In addition to having lower GPAs, $12 \%$ of first-generation students were more likely to withdraw or repeat courses they attempted, as compared to $7 \%$ for second-generation students (Chen, 2005). The purpose of this study is to determine if first-generation students majoring in business exposed to student response systems (SRS) perform better than first-generation students majoring in business not exposed to SRS. 


\subsection{First-generation students choice of major}

Choosing a major is difficult for many students, and poses a greater challenge to first-generation students in particular because their parents may be less able to offer them guidance. According to the National Center for Educational Statistics report, one out of three first-generation students (33\%) did not have a classified major after entering post-secondary education, as compared to $13 \%$ of second-generation students. Among those with a major, the most popular field for first-generation students was business at $14 \%$ followed by health science/services and social sciences at $8 \%$ and $7 \%$ respectively. Although business was by far the most popular declared major, only $32 \%$ of first-generation students who declared a business major completed their degree (Chen, 2005). For business educators at higher education institutions addressing this problem and finding ways to influence the academic performance of first-generation students majoring in business is the issue that motivates this present study.

Lower exam scores contribute to lower GPAs and to the withdrawing from or repeating of courses that firstgeneration students have attempted. This outcome of lower exam scores, with its impact on both lower GPA and on the withdrawing from and repeating of courses, contributes to a disproportionately low number of firstgeneration students majoring in business that graduate from college.

While some of the factors previously mentioned such as remedial courses and major selection, are outside the control of post-secondary educators, there are several ways to address the problems associated with in-class academic performance. One way to do so is through the use of student response systems, which has been utilized since the 1960s. Student response systems (SRS) are an in-class technology designed both to create an engaging and inviting learning environment and to increase active participation and comprehension of students, which in turn significantly increases class scores (Lowery, 2005).

\subsection{How student response systems work}

SRS improves interactive activities and thus improves learning for the following reasons. First, SRS enhances the information given to students, both by providing immediate feedback on their understanding and enabling them to compare their understanding to that of their classmates (Carnaghan \& Webb, 2007). Second, the immediacy aspect of the SRS feedback is also important, with a meta-analysis by Kulik and Kulik (1988; see also Carnaghan \& Webb, 2007) showing that studies using the actual classroom-based quizzes and learning materials have usually found immediate feedback to be more effective than delayed feedback. Third, every student is required to attempt the problem and provide the answer before receiving feedback. It is important to provided feedback before students generate responses because correct answers can "short-circuit" learning by allowing students to copy answers without an attempt to understand (Bangert-Drowns, Kulik, C.C., Kulik, J.A., \& Morgan, 1991; Carnaghan \& Webb, 2007). A benefit of having immediate feedback in the classroom is that students and instructors can improve the quality of interactive activities while a particular topic is still fresh. According to Carnaghan \& Webb, (2007), timely and unambiguous feedback, particularly when the feedback indicates problems in understanding, SRS should encourage students and professors to ask questions and to restate learning goals and techniques in response to the feedback.

\subsection{Results of previous studies regarding student response systems}

Judson and Sawada (2002) and Lowery, (2005) concluded that early uses of SRS in the 1960s and 1970s, was not associated with any difference in student performance, despite student satisfaction with the technology. It is important to note that the key difference between early studies of SRS and later studies is whether the technology was viewed as a tool for providing student feedback or instructor feedback (Judson and Sawada 2002). Earlier studies, generally utilizing a traditional lecture format, used SRS as a means to categorize student responses largely for the instructor's benefit. In contrast, more recent SRS studies have examined the technology as a means for facilitating student feedback (Lowery, 2005). Poulis, Massen, Robens, and Gilbert (1998) and Lowery, (2005) reported that the mean pass rate of students in SRS based classes were significantly higher than students who were in classes that utilized traditional response methods. Slain (2004) and Lowery (2005), noted significantly higher scores were seen when SRS was used for questions that required "analytical" type thinking consistent with Bloom's taxonomy of questioning, although the examination grades were not significantly different for questions that required strict memorization. Carnaghan \& Webb, (2007)) concluded that positive outcomes from SRS were only witnessed for the exam questions that were most similar to the in-class questions that were covered by SRS. Hill et al. (2004) utilized data from three semesters of general psychology classes in order to determine if SRS had a significant effect on exam scores. The SRS was used before the third exam to determine if scoring was higher than the previous exams. In all cases, the exams scores for the third exam were higher when SRS was used, as compared to the other two exams that didn't use SRS. 
Currently, traditional lectures impede the learning process because of insufficient active learning and feedback from students. While some researchers show that the use of SRS in lecture-based classes would help to overcome the problems of lack of active learning and feedback, which in theory would help students in the learning process, there also exists a body of literature that concludes that SRS does not have an impact on student performance.

\subsection{Method}

Six sections of a Principles of Marketing class taught over three different semesters at the University of Dubuque's School of Business \& Accounting were examined to determine the effects of SRS on first-generation students majoring in business.

Table 1 displays the breakdown of the participants by cohort for the experimental and control groups. It indicates that a total of 164 students participated in this study. Of the 164 participants, 60\% were in the experimental group, while $40 \%$ in the control group. Twenty-seven percent of the respondents were firstgeneration students, and 18\% were first-generation students majoring in business. Nineteen percent of the respondents were listed as minorities, while $34 \%$ and $66 \%$ were female and male, respectively. Forty-nine percent of the respondents were non-business majors, while $51 \%$ were business majors. As far as athletics and employment are concerned, $20 \%$ of the respondents participated in intercollegiate athletics, $71 \%$ held part/full-time jobs, and 29\% claimed they did not work. Finally, 58\% of the respondents were upper-class members, while $42 \%$ were lower-class members. These numbers indicate that the size of the sample and its variety were considerable enough to warrant such study.

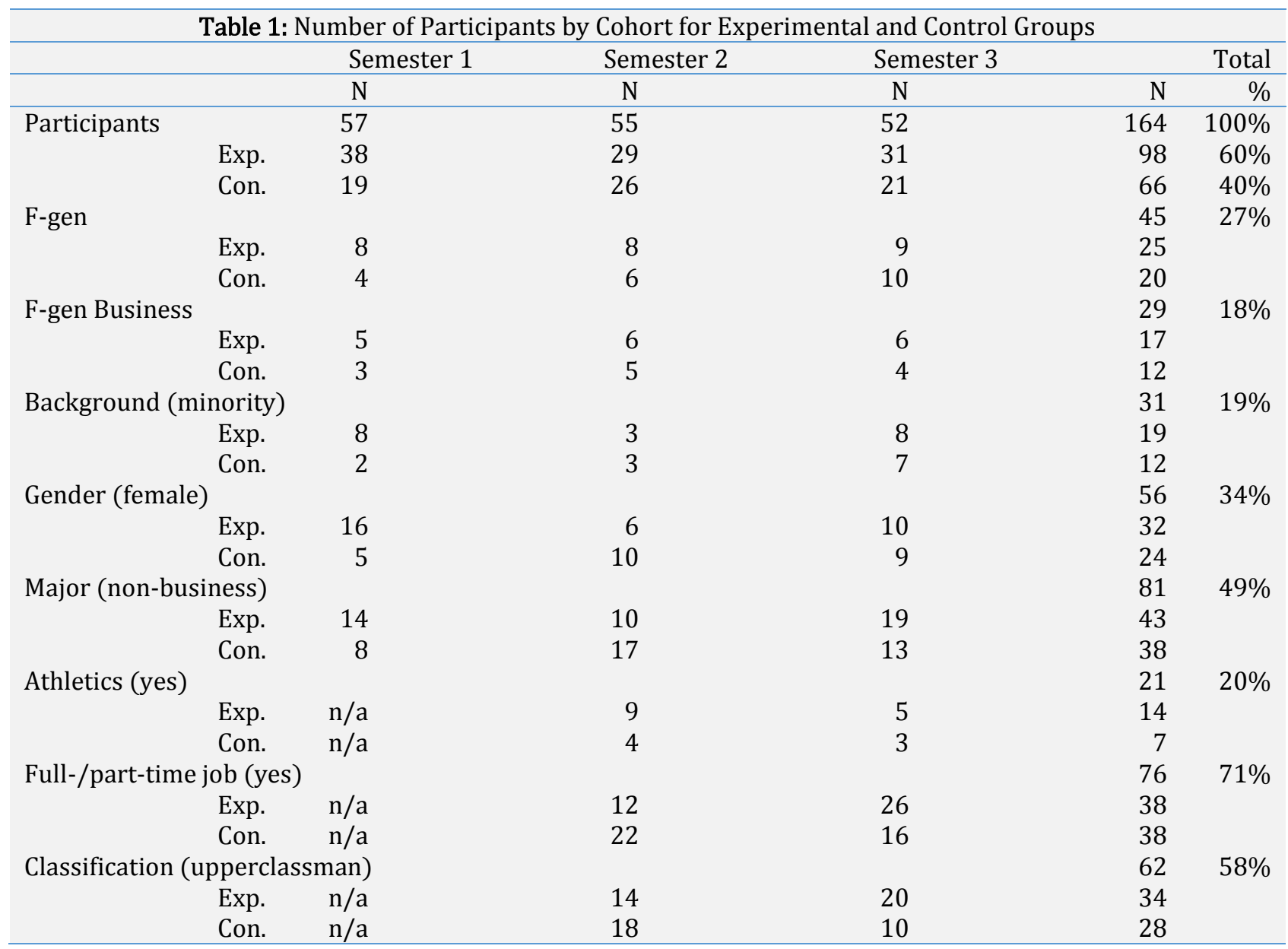

In this study, the experimental group is a set of students under consideration to determine the effects of using SRS. Results from this group are compared to those of the control group. All six sections used the same textbook and lecture style, and each was tested using the very same questions. Clearly, the difference between the two groups was that the experimental group used SRS in preparing for Test 2 and the control group did not use SRS. After the results of Test 1 were made known, students in the experimental group were told that their test average was lower than that of students in the control group (this was a true statement for all classes). The 
students were told that in an attempt to improve their test scores for Test 2, they would be asked a series of questions related to factors believed to have had an effect on their test scores (see Appendix A). Students were notified that, as part of the class, they will use the Turning Point Student Response System in the chapters leading up to Test 2. In classes in which a review was given, students received SRS remote controls upon entering the classroom and a question would appear on the screen relating to topics covered in the previous lectures (see appendix B). The students would then have an opportunity to read the question and select the answer they believed correct by pushing one of the buttons labeled \#1-5 on the remote.

After all students had responded, the results of the responses were displayed on the screen. Based upon the student responses, the instructor would either re-explained the concept if the number of correct responses were low (less than $50 \%$ of the class), or re-enforced the concept if the number of correct responses were high (greater than or equal to $50 \%$ of the class). This approach provided for immediate feedback to students to see if they understood relevant information from the previous chapter. Once all chapters related to Test 2 were reviewed, Test 2 was completed. Before the results of Test 2 were communicated, a 15-question SRS usage survey was distributed to gauge students' feelings towards the response system (see Appendix C).

\subsection{Results}

In order to determine if there were any differences in the means between the subgroups in both the experimental and control groups, an independent sample T-test was utilized. Because some of the subgroups had fewer than 30 participants, a non-parametric Mann-Whitney independent samples test was also utilized in order to validate the results of the T-test. Table 2 below shows that all of the subgroups reported no significant difference in the experimental and the control group, except for job status, which showed a significant difference between those participants who reported a full-/part-time job and those participants who did not.

Table 2: Comparison of the equality of means for test 2 of the subgroups in the experimental and control groups*

\begin{tabular}{lrrrr}
\hline Subgroup & $\mathrm{T}$ & $\mathrm{Z}$ & $\begin{array}{r}\text { T-test } \\
\text { Sig. (2-tail) }\end{array}$ & $\begin{array}{r}\text { Mann-Whitney } \\
\text { Sig. (2-tail) }\end{array}$ \\
\hline F-gen & & & .515 & .513 \\
F-gen Business & -.653 & -.654 & .904 & .903 \\
Background & -.121 & -.122 & .835 & .824 \\
Gender & -.209 & -.209 & .733 & .732 \\
Major & -.342 & -.343 & .189 & .188 \\
Athletics & 1.318 & 1.315 & .279 & .277 \\
Job Status & -1.088 & -1.087 & $.018^{*}$ & $.019^{*}$ \\
Classification & 2.407 & 2.348 & .719 & .718 \\
* Significance at 5\% level & .360 & .361 & & \\
\hline
\end{tabular}

This section provides descriptive statistics for first-generation students' majoring in business and it discusses the results of the independent samples tests between experimental and control groups. It is hypothesized that on average, first-generation college students majoring in business will have significantly higher test scores in business classes that utilized SRS than do first-generation college students majoring in business in classes that did not utilize SRS.

Table 3 shows the mean scores for first-generation students majoring in business on Tests 1 , 2, and 3 . In the experimental group, the score for Test 2 (73.88) was lower than the mean score on Test 2 for first-generation students majoring in business in the control group (76.08). This result was expected because scores from Test 1 are a predictor of the scores of Test 2. Accordingly, the control group scored higher on Test 1 (72.67) as compared to the experimental group (67.76). However as expected, the difference between the scores from Test 1 and Test 2 was greater in the experimental group (6.1176) than in the control group (3.4167).

\begin{tabular}{lcrrrrr}
\hline \multicolumn{5}{c}{ Table 3: Descriptive Statistics for First-Generation Students Majoring in Business by Test } \\
$\begin{array}{l}\text { First-gen. } \\
\text { Business }\end{array}$ & $\mathrm{N}$ & Minimum & Maximum & Mean & $\begin{array}{r}\text { Test 2- } \\
\text { Test 1 }\end{array}$ & Std. Deviation \\
\hline FGBUS1EXP & 17 & 50 & 80 & 67.7647 & & 9.71809 \\
FGBUS2EXP & 17 & 63 & 90 & 73.8824 & 6.1176 & 8.55776 \\
FGBUS1CTR & 12 & 55 & 88 & 72.6667 & & 10.36018 \\
FGBUS2CTR & 12 & 65 & 90 & 76.0833 & 3.4167 & 7.10260 \\
\hline
\end{tabular}


Table 4 shows the results of the hypothesis testing, using the independent samples T-test. Due to the smaller population size, the Mann-Whitney independent samples test was also utilized to confirm the results. The results of significance between the difference in the mean test scores and the mean difference between the scores of Test 2 and Test 1 for the experimental and control group came to .411 and .188 for the T-test, and to .363 and .128 for the Mann-Whitney test. Both results were not statistically significant, therefore failing to support the hypothesis.

\begin{tabular}{lrrrr}
\hline & \multicolumn{4}{c}{ Table 4: Independent samples test } \\
\hline F-gen Business & $\mathrm{T}$ & $\mathrm{Z}$ & $\begin{array}{r}\text { T-test } \\
\text { Sig. (2-tail) }\end{array}$ & $\begin{array}{r}\text { Mann-Whitney } \\
\text { Sig. (2-tail) }\end{array}$ \\
\hline Test 2 & & & .411 & .363 \\
Test 1-Test 2 & .830 & -.909 & .188 & .128 \\
\hline
\end{tabular}

\subsection{Conclusion}

The first approach consisted of independent samples test to determine if there was a significant difference in the scores of Test 2 compared to Test 1. Regarding the independent samples test, the study finds that the mean difference in test scores of first-generation students majoring in business in the experimental group (6.1176) was greater that the mean difference in test scores of first-generation students majoring in business in the control group (3.4167). However, a P-value of .188 indicated that the difference was not statistically significant. Looking at the results from the independent samples testing, it was expected that the mean difference between the scores of Test 2 and Test 1 for first-generation students majoring in business who were exposed to SRS would show a statistically significant improvement over the same mean difference between the scores of Test 2 and Test 1 for first-generation students majoring in business not exposed to SRS. The results indicated an improvement in the mean difference between the scores for the experimental group, but the improvement was not significant which did not support the hypothesis.

The findings imply that the use of SRS does not provide a definitive tool that instructors should use to improve test scores. The results of the study show that SRS is not a "fix-all" for low test scores. Because of the lack of significance in the mean score difference between the first-generation students majoring in business exposed to SRS and those majoring in business who were not exposed; it is implied that SRS is not an add-on that can help to increase performance, and does not substitute for other factors, such as student preparation, and motivation, or for the effective classroom preparation and the lectures of instructors.

The results of this study could have a profound effect on first-generation students, higher education, policymakers, and potential employers. First-generation students who obtain a bachelor's degree have shown little difference in their early career earnings when compared to students whose parent(s) had some college or obtained a bachelor's or higher degree (Pascarella et al., 2004). Any attempt to address and potentially offset the attrition problems of first-generation students will provide a great economic benefit not only for these students and their families, but also for generations to come.

Governmental policy-makers would also benefit from the increased graduation rates, which could be influenced by the results of this study. According to the U.S. Census Bureau (2000; see also Ishitani, 2006), the value of higher education is evidenced as a form of governmental and societal investment. The annual differential in earnings associated with educational attainment helps federal and state governments increase their tax revenues, as the number of college-educated individuals' increases. Moreover, increases in voting behavior are strongly influenced by one's educational level.

Potential employers and society would also benefit from this study. According to the results of a survey conducted by the National Association of Colleges and Employers in 2003, employers anticipated hiring about $13 \%$ more new college graduates in 2004 than in the previous year (Ishitani, 2006). In addition, the public supports the economic benefits associated with postsecondary education. A poll conducted by the Chronicle of Higher Education (1996; see also Selingo, 2003; Ishitani, 2006) indicated that the most important role for a college education is to prepare students for their future careers. It is evident that first-generation students' high attrition rates are more than just an individual student's problem; it is also a problem that affects society and its numerous stakeholders. 


\section{References}

Attinasi, L. (1989). Mexican Americans' perceptions of university attendance and the implications for freshmanyear persistence. Journal of Higher Education, 60, 247-277.

Bangert-Drowns, R. L., Kulik, C. C., Kulik, J. A., \& Morgan, M. T. (1991). The instructional effect of feedback in test-like events. Review of Educational Research, 61(2), 213-238.

Berkner, L. \& Chavez, L. (1997). Access to post-secondary education for the 1992 high school graduates (NCES 98-105). Washington, D. C.: National Center for Education Statistics, U. S. Government Printing Office.

Bilson, J. \& Terry, B. (1982). In search of the silken purse: Factors in attrition among first-generation students. College and University, 58, 57-75.

Berkner, L. Horn, L. \& Clune, M. (2000). Descriptive summary of 1995-96 beginning postsecondary students: Three years later, with an essay on students who started at less-than-4-year institutions (NCES 2000-188). Washington, D. C.: National Center for Education Statistics, U. S. Government Printing Office.

Callan, P. M. (2000). Introduction. in Measuring up 2000: the state-by-state report card for higher education. Washington, D. C.: National Center for Public Policy and Higher Education, 12-14.

Carnaghan, C. \& Webb, A. (2007). Teaching with classroom response systems: resources for engaging and assessing students with clickers. Issues in Accounting Education, 22(3), $391-409$. http://dx.doi.org/10.2308/iace.2007.22.3.391

Chen, X. (2005). First-generation students in post-secondary education: a look at their college transcripts. N. C. F. E. Statistics, 1-83

Choy, S. (2000). Debt burden four years after college (NCES 2000-188). Washington, D. C.: National Center for Education Statistics, U. S. Government Printing Office.

Chronicle of Higher Education: Almanac Issue. (1996, September). 43(1).

Grayson, P. J. (1997). Academic achievement of first-generation students in a Canadian university. Research in Higher Education, 38(6), 659-676. http://dx.doi.org/10.1023/A:1024955719648

Hill, G. W., Smith, R. A., \& Horn, M. (2004). Using technology to increase student interest, motivation, and (perhaps) learning. Retrieved May 4th, 2007 from www.smartroom.com/KSUAPA.pdf.

Horn, L. (1998). Stopouts or stayouts?: undergraduates who leave college in their first year (NCES 1999-087). Washington, D. C.: U. S. Government Printing Office.

Horn, L. \& Nunez, A. (2000). Mapping the road to college: first-generation students' math track, planning strategies, and context of support (NCES 2000-153). Washington, D. C.: National Center for Education Statistics, U. S. Government Printing Office.

Hossler, D. Schmit, J. \& Vesper, N. (1999). Going to college: how social, economic, and educational factors influence the decisions students make. Baltimore: Johns Hopkins University Press.

Ishitani, T. T. (2006). Studying attrition and degree completion behavior among first-generation college students in the United States. Journal of Higher Education, 77(5), 861-885.

Judson, E. \& Sawada, D. (2002). Learning from past and present: electronic response systems in college lecture halls. Journal of Computers in Mathematics and Science Teaching, 21(2), 167-181.

Kojaku, L. \& Nunez, A. (1998). Descriptive summary of 1995-96 beginning postsecondary students, with profiles of students entering 2- and 4-year institutions (NCES 1999-030). Washington, D. C.: National Center for Education Statistics, U. S. Government Printing Office.

Kulik, J. A. \& Kulik, C. C. (1988). Timing of feedback and verbal learning. Review of Educational Research, 58(1), 79-97. http://dx.doi.org/10.3102/00346543058001079

Lara, J. (1992). Reflections: bridging cultures. In L. Zwerling \& H. London (Eds.), First-generation students: Confronting the cultural issues. San Francisco: Jossey-Bass, 80, 65-70.

Lowery, R. C. (2005). A comparison of student-response systems for classroom teaching and learning. Conference Papers of the Midwestern Political Science Association, 1-22.

Nunez, A. M. \& Cuccaro-Alamin, S. (1998). First-generation students: undergraduates whose parent never enrolled in postsecondary education (NCES 1999-082). Washington, D. C.: U. S. Government Printing Office.

Pascarella, E. T., Pierson, C. T., Wolniak, G. C., Terenzini, P. T., et al. (2004). First-generation college students. Journal of Higher Education, 75(3), 249-284.

Pike, G. R. \& Kuh, G. D. (2005). First- and second-generation college students: a comparison of their engagement and intellectual development. Journal of Higher Education, 76(3), 276-300.

Poulis, J., Massen, C, Robens, E. \& Gilbert, M. (1998). Physics lecturing with audience paced feedback. American Journal of Physics, 66, 439-441. http://dx.doi.org/10.1119/1.18883

Pratt, P. \& Skaggs, C. (1989). First-generation college students: are they at greater risk for attention than their peers? Research in Rural Education, 6(2), 31-34.

Rendon, L., Hope, R. \& Associates. (1996). Educating a new majority: Transforming America's educational system for diversity. San Francisco: Jossey-Bass.

Richardson, R. \& Sinner, E. (1992). Helping first-generation minority students achieve degrees. In L. Zwerling \& H. London (Eds.), First-generation students: Confronting the cultural issues. San Francisco: Jossey-Bass, 80, 
29-43.

Selingo, J. (2003). What Americans think about higher education. The Chronicle of Higher Education, A10.

Slain, D. (2004). An interactive response system to promote active learning in the doctor of pharmacy curriculum. American Journal of Pharmaceutical Education, 68(5), 1-9.

Somers, P., Woodhouse, S., \& Cofer, J. (2004). Pushing the boulder uphill: the persistence of first-generation college students. NASPA Journal, 41(3), 418-435.

Stage, F. \& Hossler, D. (1989). Differences in family influences on college attendance plans for male and female ninth graders. Research in Higher Education, 30, 301-315.

Terenzini, P., Springer, L., Yaeger, P., Pascarella, E., \& Nora, A. (1996). First-generation college students: characteristics, experiences, and cognitive development. Research in Higher Education, 37, 1-22.

U. S. Census Bureau. (2000, December). Educational attainment in the United States. Current population reports. Retrieved from http://www.census.gov/prod/2000pubs/p20-528.pdf.

Warburton, E., Bugarin, R., \& Nunez, A. (2001). Bridging the gap: academic preparation and postsecondary success of first-generation students (NCES 2001-153). National Center for Education Statistics, Washington, D. C.: U. S. Government Printing Office.

Ward, C. R., Reeves, J. H., \& Heath, B. P. (2003, March). Encouraging active student participation in chemistry classes with a web-based, instant feedback, student response system. Presented at CONFCHEM: Conferences in Chemistry.

York-Anderson, D. \& Bowman, S. (1991). Assessing the college knowledge of first-generation and secondgeneration students. Journal of College Student Development, 32, 116-122.

Appendix A

In-Class Survey

Name

1. Which class(es) are you enrolled in?

A. Principles of Marketing (1:30-2:45)

B. Principles of Marketing (3:00-4:15)

2. On average, how much time do you spend studying/preparing for this/these class(es) on a weekly basis? If you are enrolled in multiple classes please label the appropriate class to the applicable study time.

A. Less than 5 hours per week

B. 6-10 hours per week

C. 11-15 hours per week

D. 16 or more hours per week

3. Do you have a full-/part-time job?
A. Yes
B. No

4. Do you participate in intercollegiate athletics?
A. Yes
B. No 
Appendix B

Review Chapter 6

Slide 1

Chpt 6 Review

Slide 2

Which is not an economic need?

1. Dependability in use

2. Hunger

3. Economy of use

4. Convenience

5. Efficiency of use

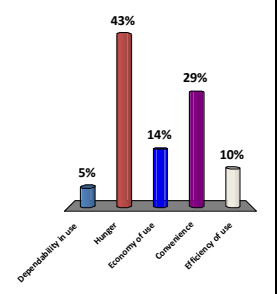

Slide 3

Which is not a psychological variable?

1. Culture

2. Personality

3. Learning

4. Perception

5. Attitudes

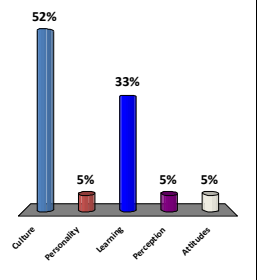

Slide 4

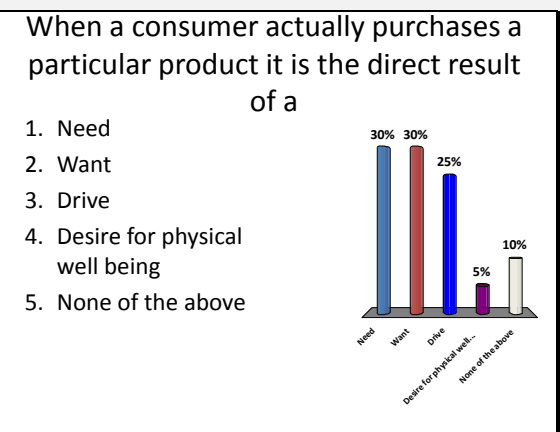

Slide 5

According to the PSSP model, the first needs most people try to satisfy are

1. Safety needs

2. Personal needs

3. Physiological needs

4. Social needs

5. Any of the above

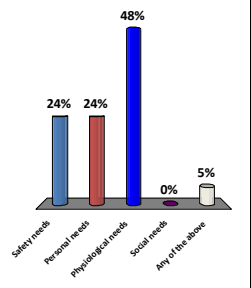




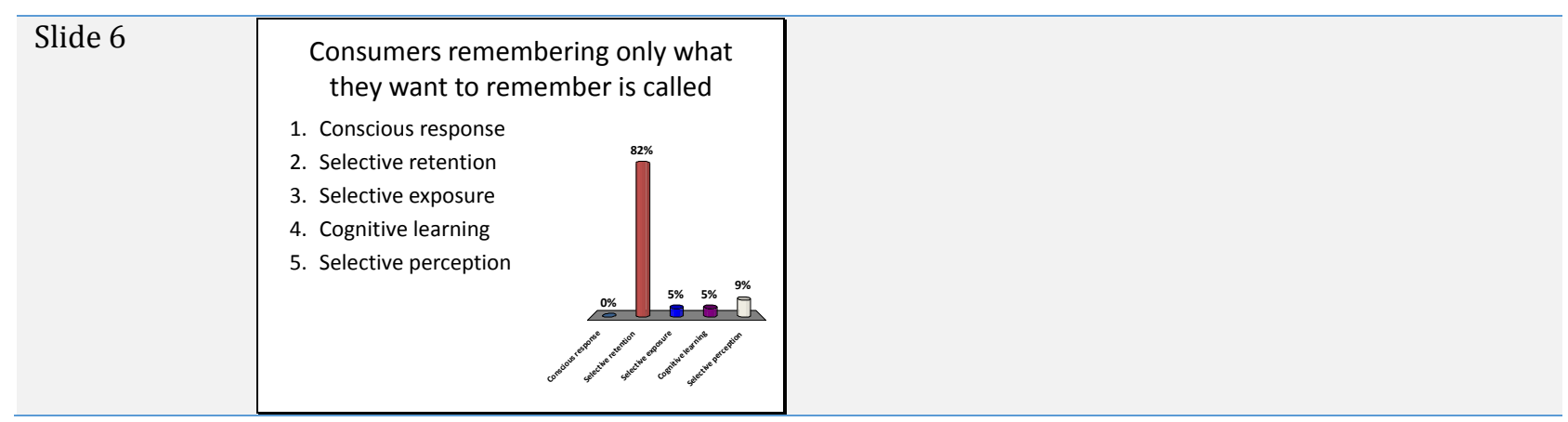

Appendix C

\begin{tabular}{|c|c|}
\hline \multicolumn{2}{|c|}{ SRS Usage Survey Questionnaire } \\
\hline Question & Response \\
\hline $\begin{array}{l}\text { 1. I am more likely to express an opinion on a survey in } \\
\text { class when the instructor asks questions that require me } \\
\text { to raise my hand in response. }\end{array}$ & $\begin{array}{l}\text { 1-strongly disagree } \\
\text { 2-disagree } \\
\text { 3-neither agree/or disagree } \\
\text { 4-agree } \\
\text { 5- strongly agree }\end{array}$ \\
\hline $\begin{array}{l}\text { 2. I am more likely to express an opinion on a survey in } \\
\text { class when the instructor asks the class to respond out } \\
\text { loud with a response. }\end{array}$ & $\begin{array}{l}\text { 1-strongly disagree } \\
\text { 2-disagree } \\
\text { 3-neither agree/or disagree } \\
\text { 4-agree } \\
\text { 5- strongly agree }\end{array}$ \\
\hline $\begin{array}{l}\text { 3. I am more likely to express an opinion on a survey in } \\
\text { class using the Student Response System. }\end{array}$ & $\begin{array}{l}\text { 1-strongly disagree } \\
\text { 2-disagree } \\
\text { 3-neither agree/or disagree } \\
\text { 4-agree } \\
\text { 5- strongly agree }\end{array}$ \\
\hline $\begin{array}{l}\text { 4. Using the Student Response System in class increases } \\
\text { my interest in the topic being discussed. }\end{array}$ & $\begin{array}{l}\text { 1-strongly disagree } \\
\text { 2-disagree } \\
\text { 3-neither agree/or disagree } \\
\text { 4-agree } \\
\text { 5- strongly agree }\end{array}$ \\
\hline $\begin{array}{l}\text { 5. Knowing that we are using the Student Response } \\
\text { System increases the likelihood that I want to attend class. }\end{array}$ & $\begin{array}{l}\text { 1-strongly disagree } \\
\text { 2-disagree } \\
\text { 3-neither agree/or disagree } \\
\text { 4-agree } \\
\text { 5- strongly agree }\end{array}$ \\
\hline $\begin{array}{l}\text { 6. The instructor's use of the Student Response System in } \\
\text { class does NOT enhance my understanding of the material. }\end{array}$ & $\begin{array}{l}\text { 1-strongly disagree } \\
\text { 2-disagree } \\
\text { 3-neither agree/or disagree } \\
\text { 4-agree } \\
\text { 5- strongly agree }\end{array}$ \\
\hline $\begin{array}{l}\text { 7. I prefer lectures and demonstrations that incorporate } \\
\text { the Student Response System. }\end{array}$ & $\begin{array}{l}\text { 1-strongly disagree } \\
\text { 2-disagree } \\
\text { 3-neither agree/or disagree } \\
\text { 4-agree } \\
\text { 5- strongly agree }\end{array}$ \\
\hline $\begin{array}{l}\text { 8. The Student Response System is just another gadget, } \\
\text { and its use distracts me during class. }\end{array}$ & $\begin{array}{l}\text { 1-strongly disagree } \\
\text { 2-disagree } \\
\text { 3-neither agree/or disagree } \\
\text { 4-agree } \\
\text { 5- strongly agree }\end{array}$ \\
\hline
\end{tabular}




\begin{tabular}{|c|c|}
\hline $\begin{array}{l}\text { 9. Using the Student Response System increases my } \\
\text { attention and participation level during class. }\end{array}$ & $\begin{array}{l}\text { 1-strongly disagree } \\
\text { 2-disagree } \\
\text { 3-neither agree/or disagree } \\
\text { 4-agree } \\
\text { 5- strongly agree }\end{array}$ \\
\hline 10. I learn more about a topic when the Student Response & 1-strongly disagree \\
\hline $\begin{array}{l}\text { System is used to gather and display immediate feedback } \\
\text { from the entire class. }\end{array}$ & $\begin{array}{l}\text { 2-disagree } \\
\text { 3-neither agree/or disagree } \\
\text { 4-agree } \\
\text { 5- strongly agree }\end{array}$ \\
\hline $\begin{array}{l}\text { 11. The Student Response System is a good tool for } \\
\text { gathering class data and opinions about a topic as a lead-in } \\
\text { to discussing the topic detail. }\end{array}$ & $\begin{array}{l}\text { 1-strongly disagree } \\
\text { 2-disagree } \\
\text { 3-neither agree/or disagree } \\
\text { 4-agree } \\
\text { 5- strongly agree }\end{array}$ \\
\hline $\begin{array}{l}\text { 12. I think questionnaires and practice tests should just be } \\
\text { handed out to individual students for their own student } \\
\text { feedback, and I am not interested in seeing the entire } \\
\text { class's responses. }\end{array}$ & $\begin{array}{l}\text { 1-strongly disagree } \\
\text { 2-disagree } \\
\text { 3-neither agree/or disagree } \\
\text { 4-agree } \\
\text { 5- strongly agree }\end{array}$ \\
\hline $\begin{array}{l}\text { 13. I like using the Student Response System to administer } \\
\text { practice questions because it indicates how well I } \\
\text { understand course content compared to my classmates. }\end{array}$ & $\begin{array}{l}\text { 1-strongly disagree } \\
\text { 2-disagree } \\
\text { 3-neither agree/or disagree } \\
\text { 4-agree } \\
\text { 5- strongly agree }\end{array}$ \\
\hline $\begin{array}{l}\text { 14. I believe that the use of the Student Response System } \\
\text { enhanced my performance on my chapter tests. }\end{array}$ & $\begin{array}{l}\text { 1-strongly disagree } \\
\text { 2-disagree } \\
\text { 3-neither agree/or disagree } \\
\text { 4-agree } \\
\text { 5- strongly agree }\end{array}$ \\
\hline $\begin{array}{l}\text { 15. I wish more of my classes used the Student Response } \\
\text { System. }\end{array}$ & $\begin{array}{l}\text { 1-strongly disagree } \\
\text { 2-disagree } \\
\text { 3-neither agree/or disagree } \\
\text { 4-agree } \\
\text { 5- strongly agree }\end{array}$ \\
\hline
\end{tabular}

